\title{
Is red blood cell distribution width a marker of severity in patients discharged from the ICU?
}

\author{
Tiago Antonio Tonietto ${ }^{1,2^{*}}$ (D), Marcio Manozzo Boniatti ${ }^{2}$, Thiago Costa Lisboa ${ }^{2}$, Marina Verçoza Viana ${ }^{2}$ and \\ Gustavo Adolpho Moreira Faulhaber ${ }^{3}$
}

\begin{abstract}
We have read the study about the association between high red blood cell distribution width and higher ward mortality after intensive care unit discharge. The study increases the evidence that RDW may be a marker of severity for patients discharged from the ICU. However, in this letter, we comment on issues that need further discussion.
\end{abstract}

Keywords: Red blood cell distribution width, RDW, Intensive care unit, Mortality

\section{Dear Editor,}

We read with interest the retrospective study by Fernandez and colleagues entitled "High red blood cell distribution width as a marker of mortality after ICU discharge: a cohort study" [1]. The authors evaluated the association between the red blood cell distribution width (RDW) with ward survival after intensive care unit (ICU) discharge and whether the RDW could improve the accuracy of the Sabadell score, a subjective tool designed to stratify patients according to ward mortality after ICU discharge. They showed that high RDW (defined as greater than $14.5 \%$ ) was associated with increased ward mortality (multivariable OR 2.8 [1.7-4.6]) and longer ward stay. Additionally, high RDW identified patients with higher ward mortality at each level of prognosis depicted by the Sabadell score, except for score 3 group. This interesting study increases the evidence that the RDW may be a marker of severity for patients discharged from the ICU. However, there are issues that need further discussion.

Firstly, in the methods section, it is stated that routine laboratory was requested by the attending physician as clinically required and the authors used the last recorded RDW before discharge to the ward. However, in the

\footnotetext{
* Correspondence: ttonietto@hcpa.edu.br

'Department of Critical Care Medicine, Hospital Nossa Senhora da Conceição, 596 Francisco Trein Ave, Porto Alegre, RS 91350-200, Brazil

²Department of Critical Care Medicine, Hospital de Clínicas de Porto Alegre, 2350 Ramiro Barcelos Street, Porto Alegre, RS 90035-903, Brazil

Full list of author information is available at the end of the article
}

results, there should have been a description of the mean time between the RDW collection and the moment of ICU discharge. This is specially important because the median ICU length of stay was $<3.5$ days and the authors did not adjust their results for the RDW collected in the ICU admission. Thus, the ward mortality could be related to high RDW at ICU admission and not at ICU discharge. The worst outcomes associated with the former have already been demonstrated in other studies [2].

Additionally, it would be interesting if the authors had reported the variation between the RDW collected at ICU discharge and ICU admission. Few studies have assessed the kinetics of the RDW and its prognostic value throughout hospitalization [3, 4]. Our group described that patients readmitted to the ICU or who died in the ward had a significantly more pronounced increase in RDW during their ICU stay than other patients (median $=0.5 \%$ and $0.2 \%$, respectively; $p=0.02$ ) [5].

Lastly, we have also demonstrated that high RDW is a marker of severity in patients discharged from the ICU to the wards [5]. We illustrated that patients with elevated RDW at ICU discharge had a significantly higher risk of ICU readmission or unexpected death in ward than patients with normal RDW (HR 1.901; 95\% CI 1.357-2.662), even after adjusting for the RDW at ICU admission and several known risk factors associated with this outcome. Furthermore, elevated RDW at discharge from the ICU was also associated with hospital mortality (HR 1.716; 95\% CI 1.141-2.580). 
Finally, practical implications of these findings include developing clinical prediction rules that consider the RDW as a relevant variable at ICU discharge. The impact of recognition of the RDW as a risk factor, leading to closer monitoring of these patients in wards, will depend on further studies assessing specific interventions.

\section{Abbreviations}

HR: Hazard ratio; ICU: Intensive care unit; OR: Odds ratio; RDW: Red blood cell distribution width

\section{Acknowledgements}

None.

Funding

Not applicable

Availability of data and materials

Not applicable.

\section{Author's contributions}

All authors participated in the preparation and writing of the manuscript. All authors read and approved the final manuscript.

\section{Ethics approval and consent to participate}

Not applicable

\section{Consent for publication}

Not applicable.

\section{Competing interests}

The authors declare that they have no competing interests.

\section{Publisher's Note}

Springer Nature remains neutral with regard to jurisdictional claims in published maps and institutional affiliations.

\section{Author details}

'Department of Critical Care Medicine, Hospital Nossa Senhora da Conceição, 596 Francisco Trein Ave, Porto Alegre, RS 91350-200, Brazil. ${ }^{2}$ Department of Critical Care Medicine, Hospital de Clínicas de Porto Alegre, 2350 Ramiro Barcelos Street, Porto Alegre, RS 90035-903, Brazil. ${ }^{3}$ Department of Internal Medicine, School of Medicine, Universidade Federal do Rio Grande do Sul,

721 Jeronimo de Ornelas Ave, Porto Alegre, RS 90040-341, Brazil.

Received: 26 December 2018 Accepted: 22 January 2019

Published online: 29 January 2019

\section{References}

1. Fernandez R, Cano S, Catalan I, Rubio O, Subira C, Masclans J, et al. High red blood cell distribution width as a marker of hospital mortality after ICU discharge: a cohort study. J Intensive Care. 2018:6:74.

2. Bazick HS, Chang D, Mahadevappa K, Gibbons FK, Christopher KB. Red cell distribution width and all-cause mortality in critically ill patients. Crit Care Med. 2011;39(8):1913-21.

3. Kim CH, Park JT, Kim EJ, Han JH, Han JS, Choi JY, et al. An increase in red blood cell distribution width from baseline predicts mortality in patients with severe sepsis or septic shock. Critical care (London, England). 2013; 17(6):R282.

4. Zhang Z, Xu X, Ni H, Deng H. Red cell distribution width is associated with hospital mortality in unselected critically ill patients. J Thorac Dis. 2013;5(6):730-6.

5. Tonietto TA, Boniatti MM, Lisboa TC, Viana MV, Dos Santos MC, Lincho CS, et al. Elevated red blood cell distribution width at ICU discharge is associated with readmission to the intensive care unit. Clin Biochem. 2018;55:15-20.

Ready to submit your research? Choose BMC and benefit from:

- fast, convenient online submission

- thorough peer review by experienced researchers in your field

- rapid publication on acceptance

- support for research data, including large and complex data types

- gold Open Access which fosters wider collaboration and increased citations

- maximum visibility for your research: over $100 \mathrm{M}$ website views per year

At BMC, research is always in progress.

Learn more biomedcentral.com/submissions 